\title{
EFFECT OF SILICA SURFACE ON THERMAL DECOMPOSITION OF THE IMMOBILIZED PEROXIDE OLIGOMERS
}

\author{
Maria Tokareva1, Stanislav Tokarev ${ }^{1}$, Volodymyr Vostres $^{1}$, Viktor Tokarev $^{1}{ }^{凶}$
}

https://doi.org/10.23939/chcht14.02.205

\begin{abstract}
The thermal decomposition of pendant peroxy groups in a cooligomer of maleic anhydride with 5-(tertbutylperoxy)-5-methylhex-1-en-3-yne as well as in its amino derivatives immobilized on different silica surfaces, has been investigated using a complex thermogravimetric analysis. Two types of silica: fumed (aerosil) and precipitated (white carbon black) ones have been surface modified by this cooligomer via diverse techniques. It has been established that in all the cases the cooligomer decomposition on the silica surface complies with the first-order kinetics. Estimated activation energy evidences lowering thermal stability of the immobilized peroxide cooligomer in comparison with its decomposition in a solution. Interestingly, on the surface of fumed silica the decomposition of peroxide cooligomers always occurs as a one-stage process, while on the surface of precipitated silica it can occur as a two-stage process. The reason for this phenomenon is a difference in the porosity and surface chemistry of these two silica samples.
\end{abstract}

Keywords: peroxide oligomers, decomposition kinetics, thermo-gravimetric analysis, silica surfaces.

\section{Introduction}

Silica, especially a high-surface-area one, ranks an important place among a wide diversity of dispersed mineral materials due to its notable properties which allow using it in many fields of science and industry, including electronics, biotechnology, agriculture, medicine, pharmacy, laboratory practice, etc. [1-4], but the greater part of manufactured silica is used as a filler for polymers. High surface area amorphous silica can be divided into a gasphase and liquid-phase $[1,5,6]$ according to its production technology. Gas-phase or pyrogenic amorphous silica (e.g. aerosil formed in a burning silicon tetrachloridehydrogen-oxygen mixture) is characterized by a high dispersity and rather low porosity of its particles (porosity factor $\approx 1.2$ ). Liquid-phase amorphous silica (white

\footnotetext{
${ }^{1}$ Lviv Polytechnic National University

12, S. Bandery St., 79013 Lviv, Ukraine

vtokarev@lp.edu.ua

(c) Tokareva M., Tokarev S., Vostres V., Tokarev V., 2020
}

carbon black) obtained via the condensation of silicic acid which is precipitated from a solution of an alkali metal silicate (so-called a sol-gel process) is also characterized by a high dispersity, either; however, its particles have greater porosity (porosity factor $\approx 2$ ).

The chemical structure of a superficial layer of amorphous silica of both types as constituting with siloxane moieties $=\mathrm{Si}-\mathrm{Si} i$ and silanol functionalities 溥- $\mathrm{OH}$; the latter locate as the separate hydroxy groups or their doublets $[5,6]$ while their surface concentration depends on the sample pre-history (e.g. production method, pre-treatments and so on), specific surface area [8]. Additionally, $\quad \mathrm{Si}-\mathrm{OH}$ concentration on the inner surface is higher than on the outer surface [7]. Adsorption properties of $\mathrm{a} \mathrm{SiO}_{2}$ substrate are connected just right with the superficial $-\mathrm{OH}$ groups.

It is a fact that covering mineral fillers with a polymer shell become more and more widespread as polymer-encapsulated particles offer actual and interesting application. Among the most promising routes to the encapsulation of mineral particles, nowadays is their modification with compounds which contain the fragments capable to generate free radicals [9-12]; amid them the method based on adsorption of polyfunctional peroxide oligomers [13-16] attracts attention, because it might be applied almost to any solid surface irrespective of their nature. Since the surface-immobilized peroxide oligomers are intended to exploit further for initiating graft polymerization, information on their reactivity is desirable to control this process effectively.

The present paper is dedicated to investigating the effect of an amorphous silica surface on the thermal decomposition of polyfunctional peroxide cooligomer immobilized on silica particles via diverse techniques.

\section{Experimental}

\subsection{Objects of Investigation}

Two silica samples were industrial trademark products, namely: Aerosil 90 (A-90) (Degussa, Germany) with a surface area $S_{s p}=93.6 \mathrm{~m}^{2} / \mathrm{g}$ and white carbon black BC-100 (Zaporizhzhya, Ukraine) with $S_{s p}=100 \mathrm{~m}^{2} / \mathrm{g}$. According to the manufactured method, the first of these 
products was pyrogenic silica while the other one was a solgel product. These two highly dispersed silicas are widely used as fillers for obtaining diverse polymer composites.

The oligomer, the structure of which is shown in Scheme 1, was derived from 5-(tert-butylperoxy)-5methylhex-1-en-3-yne (BPH) and maleic anhydride (MA). It has been chosen as a polyfunctional peroxide. BPH-MA has been adsorbed from its chloroform solutions on the surfaces of both silica samples. Considering the structure of BPH-MA it is advisable to suppose that its adsorption on the silica surface is possible due to the van der Waals forces and hydrogen bonding referred to weak interactions.

To enhance the affinity of the peroxide cooligomer towards the silica surface the tertiary amine pendants have been attached to the macrochains of the BPH-MA cooligomer via the interaction of its anhydride moieties with 2-(diethylamino)ethanol (DEAE) [17], that results in the formation of 2-(diethylamino)ethyl maleate (DEAE-Ma) moieties as shown in Scheme 1.

The obtained BPH-MA-DEAE-Ma cooligomer has been adsorbed on the silica surfaces similarly to the previous cooligomer. Attachment of tertiary amine moieties to the macromolecular chains of peroxide oligomer allows realizing its immobilization on the silica surface presumably with the formation of donor-acceptor bonds between superficial silanol groups and tertiary nitrogen atoms $[18,19]$ being stronger as simple physical adsorption linkages are in the case of BPH-MA. For this purpose, the silica surface has been previously activated via interaction of its silanol functionalities with 1,6hexamethylene diisocyanate (HMDI). After hydrolysis of the remaining unchanged isocyanate groups, they were acylated by BPH-MA cooligomer to form the adsorbed layer tethered to the silica surface as shown in Scheme 2.

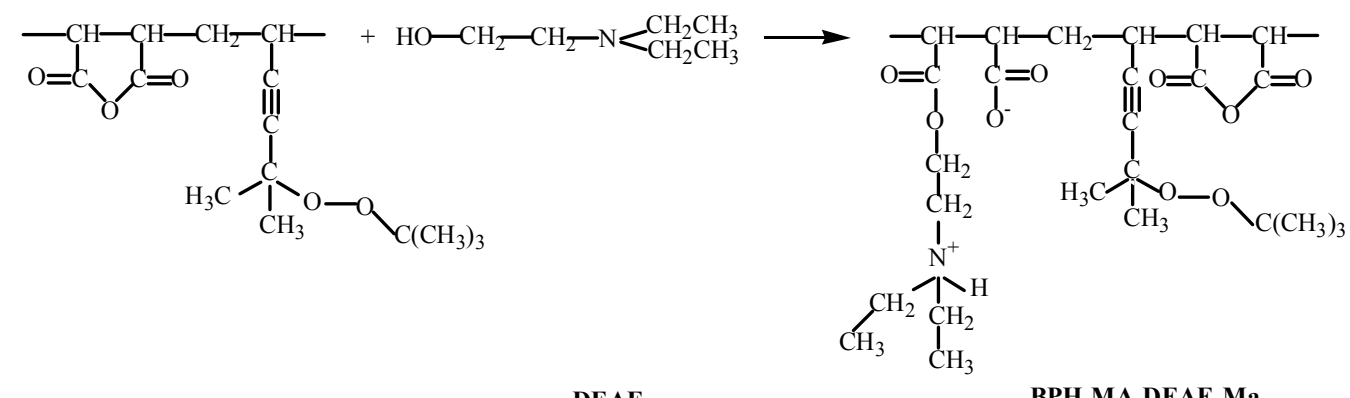

BPH-MA

DEAE

BPH-MA-DEAE-Ma

Scheme 1. Modification of BPH-MA with 2-(diethylamino)ethanol (DEAE)
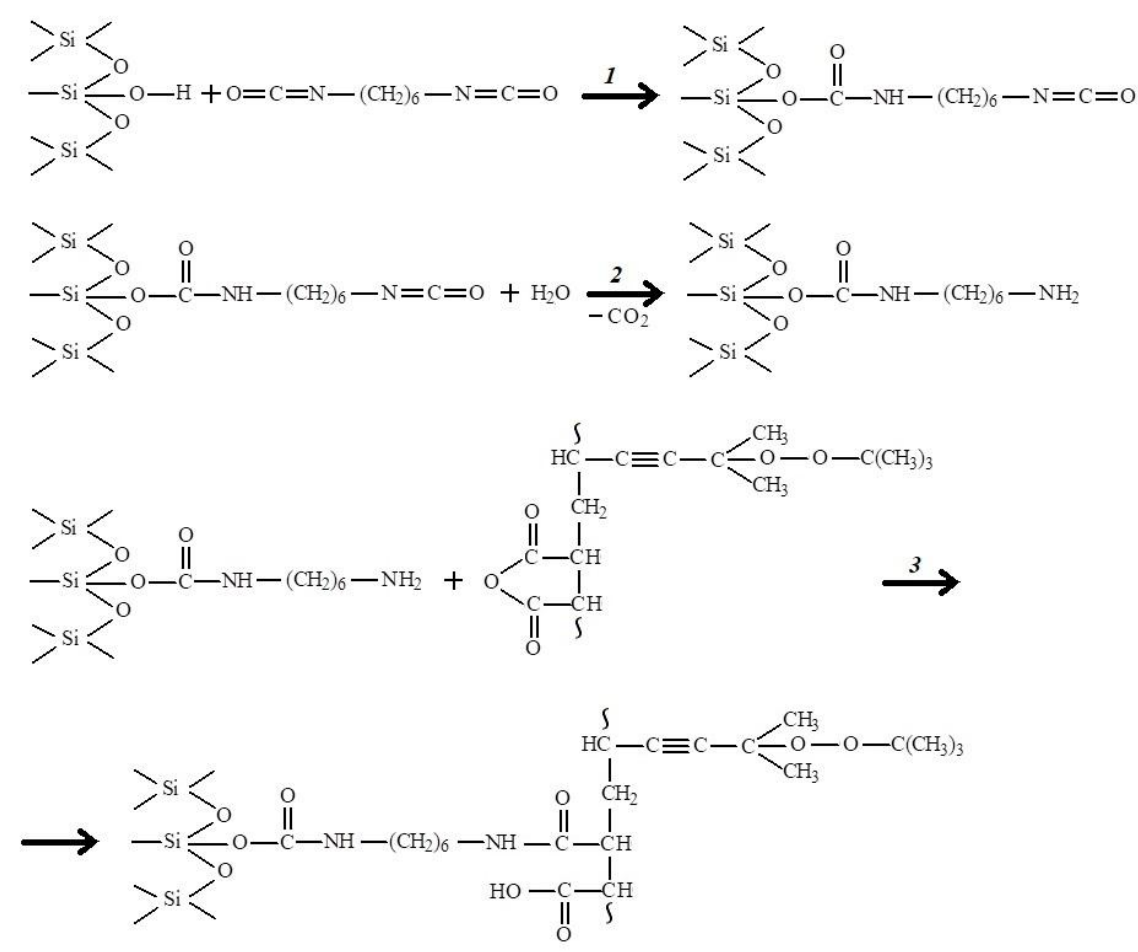

Scheme 2. The BPH-MA cooligomer tethered to silica via the HMDI spacer 


\subsection{Experimental Procedure}

MA (Fluca) was recrystallized from a chloroform solution (mp $325.7 \mathrm{~K}$, ref. mp $325.85 \mathrm{~K}[20]$ ) for BPHMA synthesis prior to use.

$\mathrm{BPH}$ was synthesized in accordance with the method given in [21] $\left(n_{D}{ }^{20} 1.4480\right.$, ref. $\left.n_{D}{ }^{20} 1.4482\right)$.

The BPH-MA cooligomer was synthesized via copolymerization of MA with BPH and subsequently purified as described elsewhere [22]. The characteristics of the obtained BPH-MA cooligomer are given in Table 1.

The BPH-MA-DEAE-Ma cooligomer was obtained via the interaction of the BPH-MA cooligomer with DEAE in accordance with Scheme 1. The reaction was performed in acetone at $333 \mathrm{~K}$ for $6 \mathrm{~h}$. The obtained BPH-MA-DEAE cooligomer was precipitated by adding toluene and then reprecipitated from acetone into toluene again. The characteristics of the BPH-MA-DEAE-Ma cooligomer are represented in Table 1. All used solvents, namely acetone, chloroform, dioxane and toluene, were of reactive grade purchased from Fluka. The adsorption of BPH-MA and BPH-MA-DEAE-Ma on the silica surface was carried out from their chloroform solutions after the pre-dispersion of silica in the solvent at ambient temperature by a mechanical high-speed stirrer at $10^{3} \mathrm{rpm}$ for $10 \mathrm{~min}$ with the solid-toliquid ratio of 1:15. The adsorption being completed, silica was separated, rinsed with acetone twice and dried until constant weight under ambient conditions. The quantity of the adsorbed cooligomer was determined by the gravimetric method as the sample weight loss after incinerating in a muffle furnace at $973 \mathrm{~K}$ for $2 \mathrm{~h}$ and from the data of the complex thermo-gravimetric analysis as well.

The modification of the A-90 surface with HMDI: A-90 previously dried in a vacuum oven (temperature $373 \mathrm{~K}$, residual pressure $2 \mathrm{~mm} \mathrm{Hg}$ ) for $8 \mathrm{~h}$ was pre-dispersed in an anhydrous toluene at $10^{3} \mathrm{rpm}$ for $10 \mathrm{~min}$. HMDI was added to this dispersion and mixed at $400 \mathrm{rpm}$ and ambient temperature for $1 \mathrm{~h}$. Surface-modified A-90 was centrifuged, thrice rinsed with the anhydrous toluene and kept under anhydrous toluene. For linking the BPH-MA macromolecules to the silica particles, some modified A-90 was separated from toluene and dispersed in a water-dioxane mixture to form terminal amine functionalities. This reaction having been completed, the sample was separated, rinsed and re-dispersed in dioxane. A solution of BPH-MA in dioxane was added to the obtained suspension and the reactive mixture was stirred thoroughly at $400 \mathrm{rpm}$ and $303 \mathrm{~K}$ for $2 \mathrm{~h}$. The A-90 with tethered BPH-MA cooligomer was separated, rinsed with acetone and dried till constant weight.

The complex thermo-gravimetric analysis was carried out within the temperature range of 293-1073 K using a Derivatograph Q-1500 D (Hungary). For calculation of activation energy according to the Kissinger equation (Eq. 3), the heating rates were varied as follows: $20.0, \quad 10.0,5.0$ and $0.6 \mathrm{~K} / \mathrm{min}$. Calculations of the decomposition rate constants were performed using the data recorded at $0.6 \mathrm{~K} / \mathrm{min}$ heating rate.

\section{Results and Discussion}

\subsection{The Decomposition of the Adsorbed BPH-MA Cooligomer}

The adsorption of the BPH-MA cooligomer on the dispersed silica surface results in immobilization on its particles the peroxide moieties capable of generating free radicals under proper conditions. As the previous investigations $[15,22]$ have shown, two types of radicals are formed during the decomposition of such peroxide moieties, namely surface-bonded macroradicals linked with the silica particles via adsorption forces and nonbonded low-molecular tert-butoxy radicals, as shown in Scheme 3. Subsequently, these radicals can either interact with proton donors via hydrogen abstraction reactions or undergo the fragmentation forming, basically, tert-butyl alcohol, acetone and methane, while other volatile products of secondary reactions can be produced as well, but in essentially quite a few amounts.

Table 1

The characteristics of the investigated peroxide cooligomers

\begin{tabular}{|c|c|c|c|c|c|c|c|}
\hline \multirow{2}{*}{ Peroxide cooligomer } & \multicolumn{3}{|c|}{ Content of monomer links, $\mathrm{mol} \%$} & \multirow{2}{*}[\eta]{, $\mathrm{dl}^{\prime} \cdot \mathrm{g}^{-1}$} & \multirow{2}{*}{$\mathrm{MM}$} & \multirow{2}{*}[\mathrm{O}_{\mathrm{act}}]{,$\%$} & \multirow{2}{*}[\mathrm{COOH}]{,$\%$} \\
\hline & $\mathrm{BPH}$ & MA & DEAE-Ma & & & & \\
\hline BPH-MA & 51.7 & 48.3 & - & 0.13 & 5,000 & 4.3 & 38 \\
\hline BPH-MA-DEAE-Ma & 51.7 & 27.6 & 20.7 & 0.06 & 6,500 & 3.4 & 22 \\
\hline
\end{tabular}

Scheme 3. The formation of volatile products at the decomposition of the peroxide moieties of the BPH-MA and its derivatives 
The effect of the A-90 and BC-100 surfaces upon the thermal stability of the peroxy groups of the immobilized BPH-MA cooligomer has been studied by the complex thermo-gravimetric analysis. This method is grounded on the analysis of the non-isothermal process as the rise in temperature versus time (curve $\mathrm{T}$ ). Simultaneously it permits to record the next parameters: the current weight of the investigated sample (curve TG), the rate of the sample weight loss (curve DTG) and the heat release (curve DTA), respectively.

The quantitative estimation of the thermal stability of the immobilized cooligomer was achieved via a mathematical treatment of the thermo-gravimetric curves (TG) recorded at various heating rates. The typical curves of the complex thermo-gravimetric analysis are shown in Fig. 1. Obviously, in the presented curves the weight loss of both investigated samples within the temperature range of $356-368 \mathrm{~K}$ is accompanied by a heat absorption. Apparently, this process can be referred to the decomposition and evaporation of volatile compounds, e.g. water adsorbed on the silica surface. For the A-90 samples with adsorbed BPH-MA cooligomer (Fig. 1b) one can additionally observe another weight loss occurred within the $373-473 \mathrm{~K}$ range, which is accompanied by the exothermic process, while no changes are detected for intact A-90 under similar conditions. This comparison allows to attribute the second weight loss step to the decomposition of the peroxy groups in the adsorbed BPH-MA cooligomer.

The weight loss curves for the investigated A-90 and BC-100 samples with adsorbed BPH-MA are presented in Figs. 2 and 3. Evidently, the experimental data are quite reproducible. The shapes of the weight loss curves are somewhat different for A-90 and for BC-100, which is obviously due to the differences between their surface morphologies.

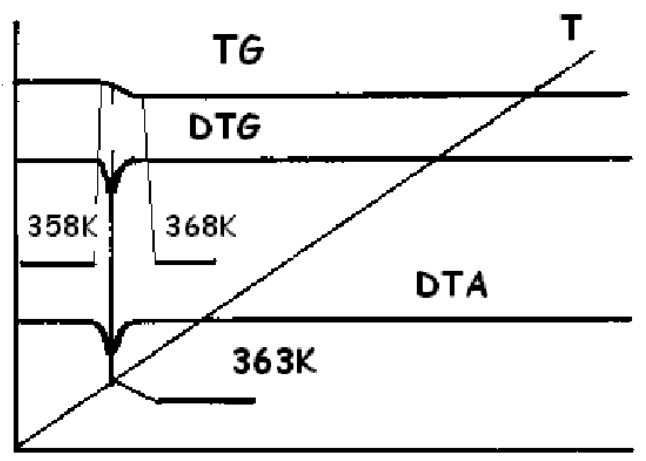

a)

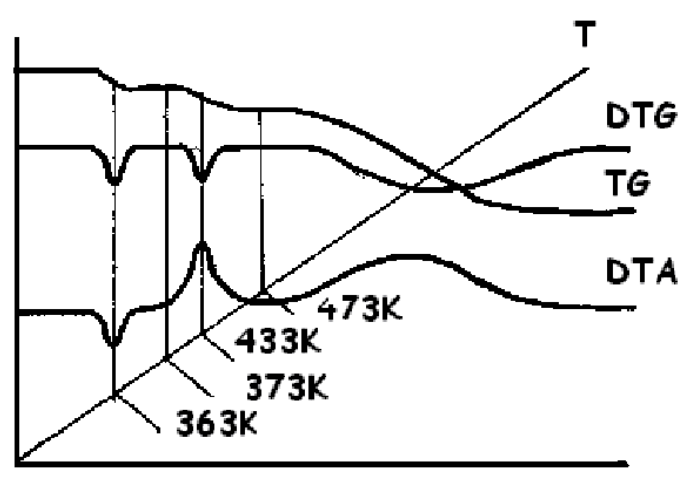

b)

Fig. 1. The complex thermo-gravimetric analysis curves of intact A-90 (a) and A-90 with adsorbed BPH-MA (b)

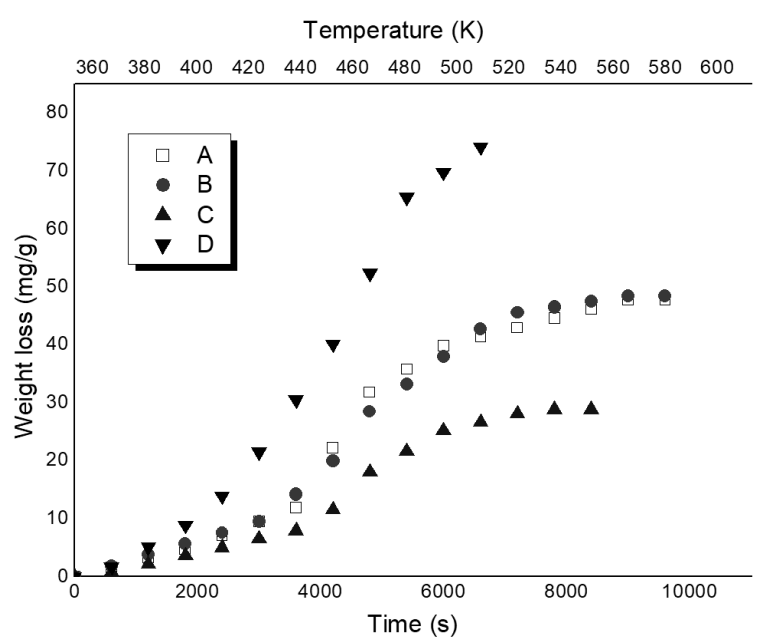

Fig. 2. The weight loss of the A-90 samples with adsorbed BPH-MA against heating time and temperature. An amount of BPH-MA adsorbed on the silica surface, $\mathrm{mg} / \mathrm{g}$ : 100 (A, B); $56(\mathrm{C})$ and 140 (D)

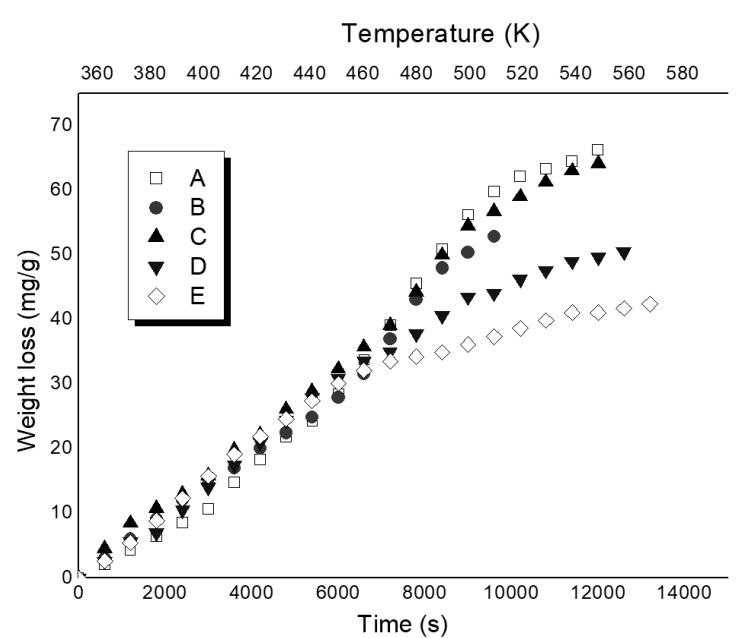

Fig. 3. The weight loss of the $\mathrm{BC}-100$ samples with adsorbed $\mathrm{BPH}-\mathrm{MA}$ against heating time and temperature. An amount of BPH-MA adsorbed on the silica surface, $\mathrm{mg} / \mathrm{g}$ : 150 (A, B, C); 100 (D) and 80 (E) 
The obtained results on the weight losses enable to calculate the concentration of the residual (nondecomposed) peroxide moieties (C) at any given point of the experiment, i.e. at the certain temperature and time. The calculations are based on the difference between the maximal and current weight losses. It is postulated for these calculations that the mechanism of decomposition, as well as the output of the decomposition products, do not depend on the peroxy group conversion.

The rates of decomposition $W$ have been estimated by numerical differentiation of the obtained experimental curves presented in Figs. 2 and 3. The order $n$ of this reaction with respect to the peroxy group concentration has been calculated applying Eq. (1) and using the results derived from the mathematical treatment of the experimental thermo-gravimetric curves recorded for the silica samples with various quantity of the adsorbed BPHMA cooligomer. The estimated values of $n$ are presented in Table 2.

$$
n=\frac{\left(\ln W_{1}-\ln W_{2}\right)}{\left(\ln C_{1}-\ln C_{2}\right)}
$$

where $C_{1}$ and $C_{2}$ are the peroxide group concentrations on the silica surface, $\mathrm{mol} / \mathrm{m}^{2} ; W_{1}$ and $W_{2}$ are the corresponding reaction rates at the given temperature and time, $\mathrm{mol} /\left(\mathrm{m}^{2} \cdot \mathrm{s}\right)$. The subscripts correspond to two silica samples with different quantities of peroxide oligomer.
The submitted data indicate that the decomposition of the BPH-MA peroxide moieties on the A-90 and BC100 surfaces could be well described with the first-order kinetic equation within all the investigated temperature range. Therefore, for calculating the effective rate constants of the peroxide group decomposition $k_{d}$ the following equation has been applied:

$$
k_{d}=W_{T} / C_{T}
$$

where $W_{T}$ is the reaction rate, $\mathrm{mol} /\left(\mathrm{m}^{2} \cdot \mathrm{s}\right) ; C_{T}$ is the concentration of the peroxide moieties at the temperature $T, \mathrm{~K}$.

The obtained values of the effective rate constants for the decomposition of the peroxy groups for the BPH-MA adsorbed on the A-90 surface in the Arrhenius plot together with the activation energy $E_{a}$ of this process are shown in Fig. 4. It is noteworthy that the experimental points are well linearized (correlation coefficient $K=0.98259$ ); this is indicative of the first order for that reaction.

The investigation of the BPH-MA peroxy group decomposition on the A-90 surface, performed at various heating rates, allows to estimate the effective activation energy of the process applying the Kissinger equation [23]:

$$
-\beta / T_{\max }{ }^{2}=\left(k_{d} \cdot R / E_{a}\right) \cdot n \cdot C^{n-1} \cdot \exp \left\{-E_{a} / R T_{\max }\right)
$$

where $\beta$ is the heating rate, $\mathrm{K} / \mathrm{s} ; T_{\max }$ is the temperature which corresponds to the maximum in the curve of the weight loss rate (DTA), $\mathrm{K}$.

Table 2

The reaction order for the peroxide group decomposition for BPH-MA adsorbed on the A-90 and BC-100 surfaces

\begin{tabular}{|c|c|c|c|c|c|c|c|}
\hline Temperature, $\mathrm{K}$ & 393 & 403 & 413 & 423 & 433 & 443 & Average value \\
\hline$n_{\mathrm{A}-90}$ & 1.10 & 1.19 & 1.10 & 0.75 & 0.95 & 0.95 & $1.01 \pm 0.12$ \\
\hline$n_{\mathrm{B}-100}$ & 1.04 & 0.96 & 1.00 & 1.18 & 1.13 & 0.89 & $1.03 \pm 0.09$ \\
\hline
\end{tabular}

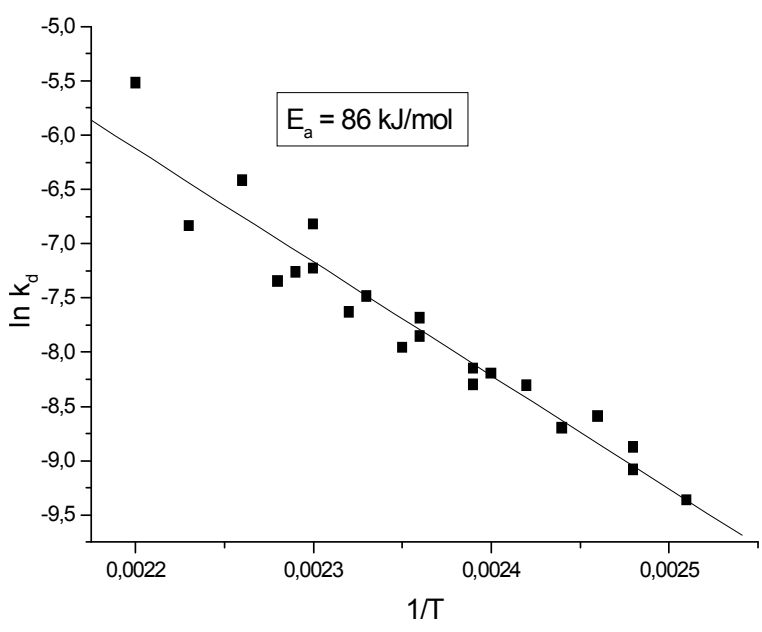

Fig. 4. $\ln k_{d} v s$. reciprocal temperature $1 / T$ for the BPH-MA decomposition on the A-90 surface

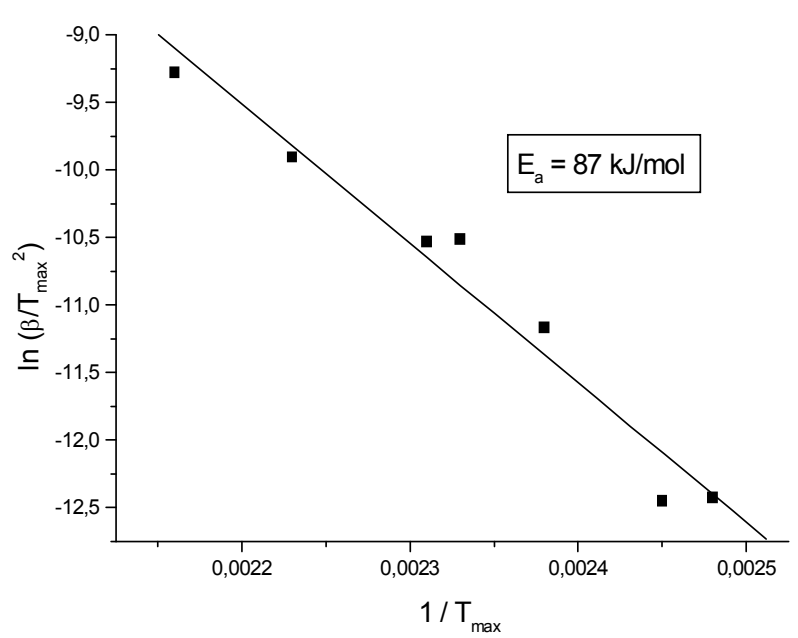

Fig. 5. $\ln \left(\beta / T_{\max }{ }^{2}\right) v s .1 / T_{\max }$ for the BPH-MA decomposition on the A-90 surface 


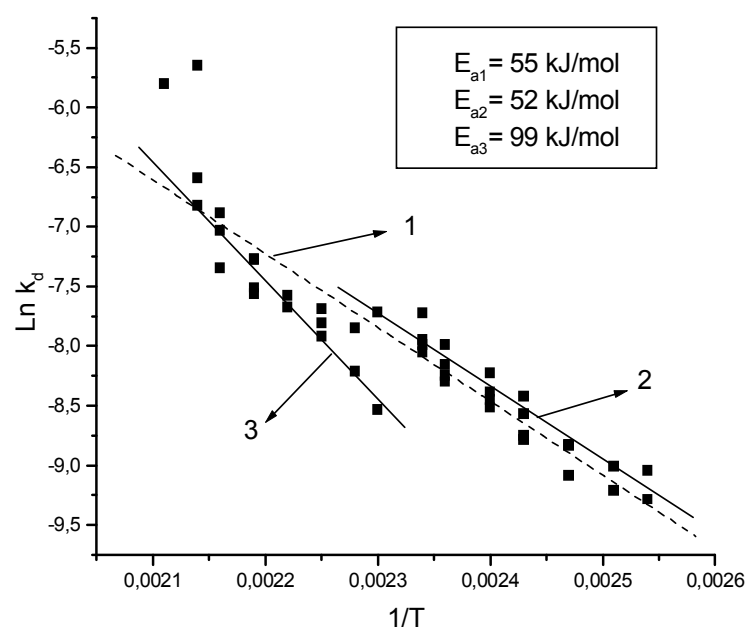

Fig. 6. $\ln k_{d} v s .1 / T$ for the decomposition of BPH-MA adsorbed on BC-100

Hence $E_{a}$ can be easily calculated from the slope of an approximating straight line plotted in the $\ln \left(\beta / T_{\max }{ }^{2}\right) v s$. $1 / T_{\max }$ coordinates (Fig. 5). The data presented in Fig. 5 demonstrate that the experimental points are well linearized $(K=0.9803)$. The activation energy of the BPH-MA decomposition on the A-90 surface has been calculated as $87 \pm 7 \mathrm{~kJ} / \mathrm{mol}$ which correlates well with the value obtained above from the data in Fig. 4. This fact can serve as a good evidence that the decomposition of BPHMA adsorbed on the A-90 surface complies with the firstorder kinetics.

In the case of $\mathrm{BC}-100$ the process of the peroxide cooligomer decomposition is more complicated (Fig. 6). It is easy to notice that within the entire investigated range, a simple straight line (line 1) does not fit well to a set of experimental points, as the same follows from the obtained value of the correlation coefficient $K_{1}=0.89454$. However, when calculating the effective activation energy applying the summarized data from Fig. 6, the $E_{a 1}$ value equal to $55 \pm 3 \mathrm{~kJ} / \mathrm{mol}$ was obtained (the calculation model based on the usual Arrhenius equation). The calculation based on the Kissinger equation (Eq. (3)), which is shown graphically in Fig. 7, gives $E_{a}=74 \pm 7 \mathrm{~kJ} / \mathrm{mol}$ at $K=0.98674$.

Thus, in the case of BC-100 the activation energy values, which were obtained in different ways, do not correlate with each other; moreover, both of them are lower than the values inherent in the decomposition of BPH-MA adsorbed on the A-90 surface.

At the same time, a visual analysis of the point distribution in Fig. 6 prompts to suggest that the decomposition of BPH-MA adsorbed on the BC-100 surface occurs as a two-stage process. Accepting this model, the experimental points depending on the temperature might be divided into two ensembles, within

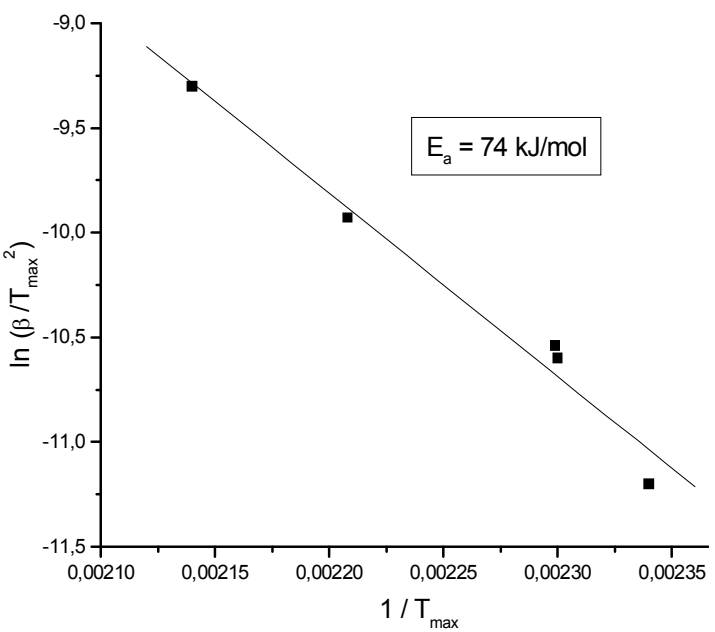

Fig. 7. $\ln \left(\beta / T_{\max }{ }^{2}\right)$ vs. $1 / T_{\max }$ for the decomposition of BPH-MA adsorbed on BC-100

which they have aligned. Indeed, the experimental dependence of the decomposition rate constant in the Arrhenius plot is quite well linearized within two diverse temperature ranges of $383-433$ and $433-473 \mathrm{~K}$ (Fig. 6, lines 2 and 3) with the corresponding correlation coefficients $K_{2}=0.99096$ and $K_{3}=0.98566$. Accordingly, this procedure gives two diverse values of the effective activation energy for each stage, which are $E_{a 2}=55 \pm 3 \mathrm{~kJ} / \mathrm{mol}$ and $E_{a 3}=99 \pm 12 \mathrm{~kJ} / \mathrm{mol}$ for the first and second temperature ranges respectively.

The distinctions in the behaviour of the peroxide cooligomer adsorbed on the $\mathrm{BC}-100$ and A-90 particles are apparently attributed to the difference in the peculiarities of morphology (in the first instance porosity) and surface chemistry of these substrates. In the next part, these differences will be considered more particularly.

\subsection{The Decomposition of the Adsorbed BPH-MA-DEA-Ma Cooligomer}

The complex thermo-gravimetric analysis of both the A-90 and BC-100 samples with adsorbed BPH-MADEAE-Ma cooligomer (Fig. 8) has shown that its peroxide moieties decompose in the temperature range of $373-473 \mathrm{~K}$ similarly to those case of adsorbed BPH-MA. Nevertheless, all the weight loss curves for the BPH-MADEAE-Ma decomposition on both the A-90 and BC-100 surfaces have a similar shape, while at the decomposition of BPH-MA the distinguished shapes of the weight loss curve have been observed for these two substrates (Figs. 2 and 3). This evidence seems to point in the absence of the effect of silica porosity or at least its non-essential influence on the stability of the peroxy groups. The values of the reaction orders with respect to the BPH-MADEAE-Ma peroxy groups, which derived from the experimental data, are shown in Table 3. 
The reaction order for the peroxy group decomposition of BPH-MA-DEAE-Ma adsorbed on the A-90 and BC-100 surfaces

\begin{tabular}{|c|c|c|c|c|c|c|c|c|}
\hline Temperature, $\mathrm{K}$ & 383 & 389 & 395 & 401 & 421 & 427 & 433 & Average value \\
\hline$n_{\mathrm{A}-90}$ & 0.87 & 0.79 & 1.01 & 1.44 & 1.04 & 0.76 & 0.80 & $0.96 \pm 0.15$ \\
\hline$n_{\mathrm{BC}-100}$ & 1.15 & 1.47 & 1.21 & 0.74 & 0.7 & 0.67 & 0.74 & $0.95 \pm 0.28$ \\
\hline
\end{tabular}

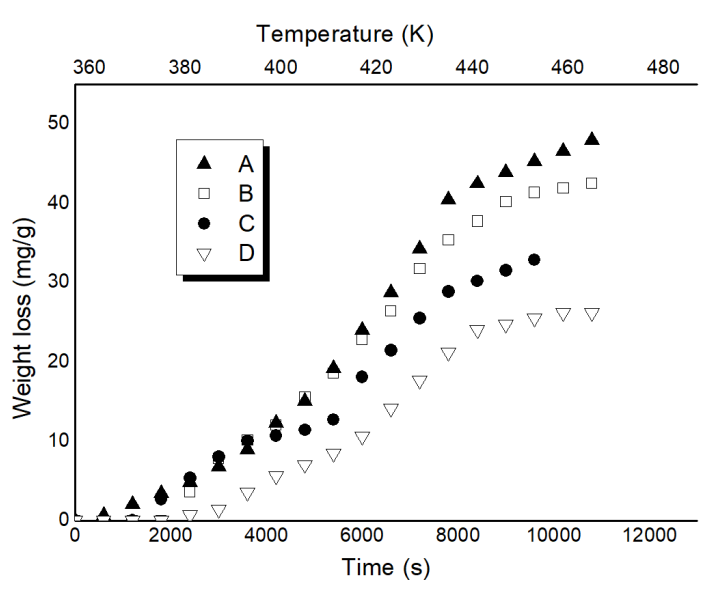

Fig. 8. The weight loss of the A-90 (A, D) and BC-100 (B, C) samples with adsorbed BPH-MA-DEAE-Ma $v s$. heating time and temperature. An amount of BPH-MA-DEAE-Ma adsorbed on the silica surface, mg/g: 167 (A); 132 (B); 106 (C) and 77 (D)

Apparently, the decomposition of the BPH-MADEAE-Ma cooligomer on both the A-90 and BC-100 surfaces complies the first-order kinetics, as follows from Table 3. The effective rate constants in the Arrhenius plot are shown in Fig. 9 (points) and the activation energy of the process thereon is given there. Interestingly, the points belonging to both the cases of A-90 (A, D) and BC-100 $(\mathrm{B}, \mathrm{C})$ surround one straight line $(K=0.97408)$, that corresponds to activation energy of $84 \pm 7 \mathrm{~kJ} / \mathrm{mol}$. The effective activation energy calculated according to the Kissinger equation (Fig. 10) is equal to $89 \pm 7 \mathrm{~kJ} / \mathrm{mol}$ $(K=0.99396)$. The obtained values of $E_{a}$ correlate quite well with those for the BPH-MA decomposition on the A-90 surface.

\subsection{The Decomposition of the BPH-MA Tethered via HMDI}

The thermo-gravimetric investigations of the A-90 samples with the BPH-MA tethered to the silica surface via HMDI were carried out similarly to those described above. Calculations performed using the Arrhenius equation (Fig. 11) give effective activation energy equal to $86 \pm 5 \mathrm{~kJ} / \mathrm{mol}(K=0.98259)$; this value coincides well with the parameters obtained in the previous investigations (Figs. 4 and 9).

The following main regularities are attributed to the process of peroxide cooligomer decomposition on the

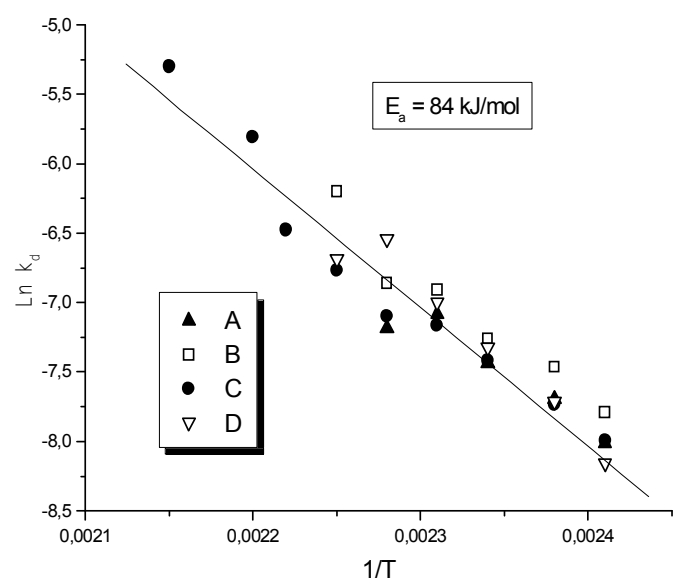

Fig. 9. $\ln k_{d} v s .1 / T_{\max }$ for the BPH-MA-DEAE-Ma decomposition on the A-90 (A, D) and BC-100 (B, C) surfaces

silica surface as it follows by summarizing the above data. The thermal stability of the peroxide moieties on the A-90 surface seems to be not influenced by the method used for BPH-MA cooligomer immobilization and the average value of activation energy for the decomposition of both these substrates is $86 \pm 8 \mathrm{~kJ} / \mathrm{mol}$. Moreover, this value correlates quite well with activation energy found for the decomposition of the same cooligomer immobilized on mineral particles of other nature as the process of the decomposition was carried out in an organic medium [13]. For instance, $E_{a}$ has been found to be $94 \pm 10 \mathrm{~kJ} / \mathrm{mol}$ for the BPH-MA cooligomer decomposition on the surface of $\mathrm{CaCO}_{3}$ particles dispersed in toluene. It is noteworthy that the decomposition of this cooligomer in the solution is characterized by appreciably higher activation energy being equal to $124 \pm 7 \mathrm{~kJ} / \mathrm{mol}$ [22]. Thus, the immobilization of the peroxide cooligomer on any solid surface lowers its thermal stability. The reasons are diverse electronic, polar and steric effects of the solid surface as well as increased difficulties in an energy excess dissipation by the immobilized macromolecules [24].

The decomposition of the peroxide cooligomers immobilized on the BC-100 surface occurs either as a two-stage process which attributed to the thermolysis of adsorbed BPH-MA or as an ordinary process that is similar to the decomposition on the A-90 surface; just that very case is observed for adsorbed BPH-MA-DEAE-Ma. 


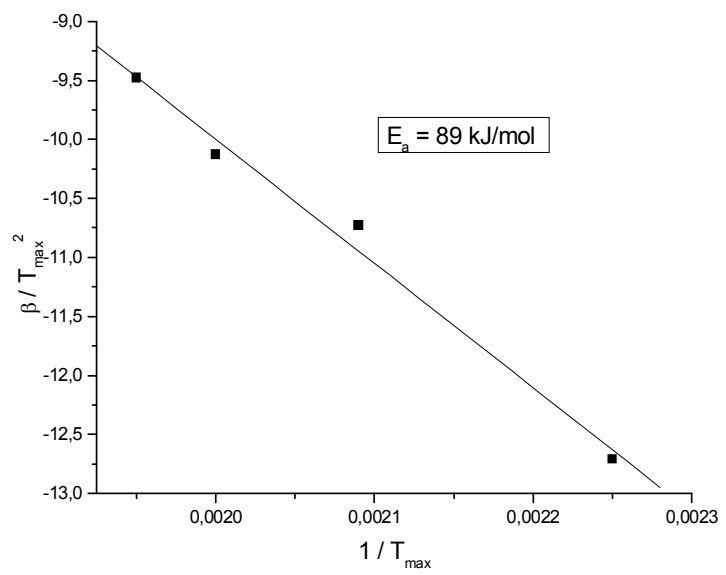

Fig. 10. $\ln \left(\beta / T_{\max }{ }^{2}\right) v s .1 / T_{\max }$ for the decomposition of BPH-MA-DEAE-Ma on the A-90 surface

Such an appreciable difference in the behaviour of these cooligomers (despite the similarity of their structures) immobilized on the surfaces of these two different types of silica can be explained taking into account morphology and surface chemistry of silica obtained either by fuming or by wet precipitation technique.

Fumed silica has a non-porous smooth surface with rather low surface concentration of silanol groups (2-3 groups per sq $\mathrm{nm}$ ) and low acidity $[1,4,6]$. This explains no effect of the method used for the immobilization of the peroxide cooligomers on the surface of fumed silica.

On the contrary, the precipitated silica is characterized by a considerable porosity and several times as much higher total concentration of silanol groups compared with fumed silica $[1,6]$. Consequently, during adsorption the adsorbed peroxide cooligomers can locate on both the outer surface of the silica particles and on the surface of their pores. But the surface chemistry of these two surfaces in the precipitated silica is quite different. While the outer surface of precipitated silica has the concentration of the silanol groups similar to that on the surface of fumed silica; the concentration of the silanol groups on the pore surface of precipitated silica can reach 12 groups per sq $\mathrm{nm}$ [6]. Moreover, these pores can contain some residue of silicic acid, thus acidity of the pore surface should be much higher as acidity of the outer surface of the silica particles. A higher acidity of the pore surface can provoke lowering the thermal stability of the BPH-MA peroxy groups immobilized in the pores. As a result, the decomposition of BPH-MA adsorbed on the BC-100 occurs as a two-stage process with two different activation energies (Fig. 6). The lowest Ea is attributed to the decomposition of the portion of the BPH-MA macromolecules immobilized in pores, while higher Ea is attributed to the decomposition of the portion of the BPHMA macromolecules immobilized on the outer surface of

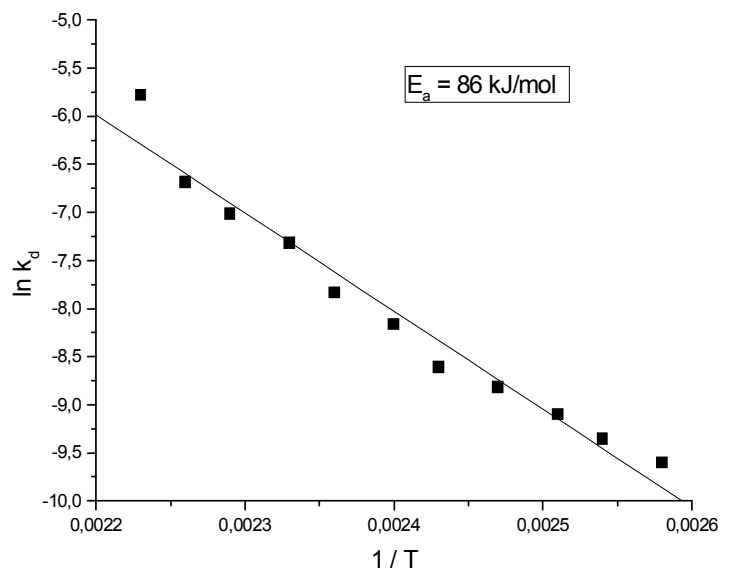

Fig. 11. $\ln k_{d} v s .1 / T$ for the decomposition of BPH-MA linked to the A-90 surface via HMDI

the BC-100 particles. The analysis of the experimental data (Fig. 3) shows that approximately $40 \%$ of the total quantity of the peroxy groups of BPH-MA, adsorbed on the BC-100 surface, are strongly influenced by the surface, which correlates with a porosity factor for this substrate quite well.

If BPH-MA-DEAE-Ma is adsorbed on the BC-100 surface, it decomposes similarly to the decomposition of this peroxide cooligomer on the A-90 surface (look at Fig. 9). It can be supposed that the tertiary amino groups of BPH-MA-DEAE-Ma neutralize the excess of acidity in the pores of $\mathrm{BC}-100$.

\section{Conclusions}

The complex thermo-gravimetric analysis has been used to study the thermal decomposition of the peroxide cooligomers immobilized on the surfaces of both fumed and precipitated silica. The performed investigations show that the immobilization of the peroxide cooligomers on any silica surfaces lowers the activation energy of the thermolysis for the cooligomer peroxy groups. The higher acidity of the pore surface of the precipitated silica is a reason for additional lowering activation energy for the decomposition of the peroxide cooligomer immobilized there. Thus, a two-stage process of decomposition of the peroxide cooligomer immobilized on the precipitated silica particles can be explained as its decomposition on two different silica surfaces namely: the outer particle surface with the lower acidity and the pore surface with the higher acidity. The introduction of amino groups into the structure of the peroxide cooligomer neutralizes the excess acidity of the pore surface and the decomposition of this cooligomer immobilized on the precipitated silica particles occurs as a one-stage process similarly to the decomposition on the fumed silica particles. 


\section{References}

[1] G. Wypych.: Handbook of Polymers, $2^{\text {nd }}$ edn. Chem.Tec. Publ., Toronto 2016.

[2] Shibanova O., Medvedevskikh Y., Voronov S. et al.: Polym. Sci. Ser. A, 2002, 44, 258.

[3] Barua S., Gogoi S., Khan R., Karak N.: Raw Mater. Appl., 2019, 261. https://doi.org/10.1016/b978-0-12-814615-6.00008-4

[4] Narayan R., Nayak U., Raichur A., Garg S.: Pharmaceutics, 2018, 10, 118. https://doi.org/10.3390/pharmaceutics 10030118 [5] Barthel H., Rosch L., Weis J.: Fumed Silica - Production, Properties, and Applications [in:] Auner N., Weis J., Organosilicon Chemistry II: From Molecules to Materials, 1996, 761-778. https://doi.org/10.1002/9783527619894.ch91

[6] Lazareva S., Shikina N., Tatarova L., Ismagilov Z.: Eurasian Chem. Technol. J., 2017, 19, 295. http://doi.org/10.18321/ectj677 [7] Bergna H.: The Colloid Chemistry of Silica. 1994, ch.1, 1-47. https://doi.org/10.1021/ba-1994-0234.ch001

[8] Ab Rahman I., Vejayakumaran P., Sipaut C. et al.: Mater. Chem. Phys., 2009, 114, 328.

https://doi.org/10.1016/j.matchemphys.2008.09.068

[9] Sugawara T., Matsuda T.: Macromolecules, 1994, 27, 7809. https://doi.org/10.1021/ma00104a040

[10] Jung D., Park I., Choi Y. et al.: Langmuir, 2002, 18, 6133. https://doi.org/10.1021/la025558u

[11] de la Vega Oyervides A., Bonilla Ríos J., Ramos de Valle L., Schulte K.: Macromol. Mater. Eng., 2007, 292, 1095.

https://doi.org/10.1002/mame.200700201

[12] Maslowski M., Miedzianowska J., Strzelec K.: Cellulose, 2018, 25, 4711. https://doi.org/10.1007/s10570-018-1880-6

[13] Voronov S., Tokarev V., Datsyuk V. et al.: J. Appl. Polym. Sci., 2000, 76, 1228. https://doi.org/10.1002/(SICI)10974628(20000523)76:8<1228::AID-APP3>3.0.CO;2-8

[14] Tokarev V., Voronov S., Adler H. et al.: Macromol. Symp., 2002, 187, 155. https://doi.org/10.1002/1521-

3900(200209)187:1\%3C155::AID-MASY155\%3E3.0.CO;2-H

[15] Shevchuk O., Wagenknecht U., Wiessner S. et al.: Chem.

Chem. Technol., 2015, 9, 149.

https://doi.org/10.23939/chcht09.02.149

[16] Shevchuk O., Bukartyk N., Nadashkevych Z., Tokarev V.:

Chem., Technol. Appl. Substances, 2019, 2, 153.

https://doi.org/10.23939/ctas2019.01.153

[17] Shafranska O., Tokarev V., Voronov A. et al.: Langmuir, 2005, 21, 3459. https://doi.org/10.1021/la0482453

[18] Rochester C., Yong G.: J. Chem. Soc., 1980, 76, 1158. https://doi.org/10.1039/F19807601158

[19] Dudik O.: Poverhnya, 2013, 5, 112.

https://surfacezbir.com.ua/index.php/surface/article/view/
[20] Musa O.: Handbook of Maleic Anhydride Based Materials: Syntheses, Properties and Applications. Springer 2016.

[21] Vilenskaya M., Kharamov D., Sorokin E. et al.: Khim. Promyshlennost, 1970, 7, 399.

[22] Voronov S., Tokarev V., Lastukhin Yu., Oduola K.: J. Appl. Polym. Sci., 2000, 76, 1217. https://doi.org/10.1002/(SICI)10974628(20000523)76:8<1217::AID-APP2>3.0.CO;2-F

[23] Robbins D., Almquist A., Timm D. et al.: Macromolecules, 1995, 28, 8729. https://doi.org/10.1021/ma00130a004

[24] Johannsmann D., Reviakine I., Richter R.: Anal. Chem., 2009, 81, 8167. https://doi.org/10.1021/ac901381z

Received: November 11, 2019 / Revised: December 05, 2019 / Accepted: March 16, 2020

\section{ВПЛИВ ПОВЕРХНІ $\mathrm{SiO}_{2}$ \\ НА ТЕРМІЧНИЙ РОЗКЛАД ІММОБІЛІЗОВАНИХ ПЕРОКСИДНИХ ОЛІГОМЕРІВ}

Анотація. Термічний розклад пероксидних груп у структурі коолігомеру малеїнового ангідриду з 5-третбутилперокси-5-метилгекс-1-ен-3-іном, а також його амінопохідної, іммобілізованих на поверхніх різних видів $\mathrm{SiO}_{2}$ було досліджено за допомогою комплексного термогравіметричного аналізу. Два види $\mathrm{SiO}_{2}$, a cаме піролізний - аеросил та осаджений - біла сажа поверхнево були модифіковані циими коолігомерами різними методами. Встановлено, щзо у всіх випадках розклад коолігомеру на поверхні діоксиду кремнію під порядковується кінетичному рівнянню першого порядку. Оцінені енергї активації свідчать про зниження термічної стабільності пероксидного коолігомеру у порівнянні з його розкладом у розчині. Показано, щчо на поверхні аеросилу розклад пероксидного коолігомеру завжди відбувається як одностадійний прочес незалежно від методу модифікації, тоді як на поверхні білої сажі він може відбуватися як одностадійний чи двостадійний процес в залежності від методу модифікаиіі. Причиною цьього феномену є різниця в пористості та в хіміі поверхонь циих двох видів діоксиду кремнію.

Ключові слова: пероксидний олігомер, кінетика розкладу, термогравіметричний аналіз, поверхні діоксиду кремнію. 